\title{
Studi Intensitas Cahaya Matahari Dengan Data Logger Untuk Efektiv Penempatan Panel Surya
}

\author{
Asnal Effendi ${ }^{1}$, Arfita Yuana Dewi', Siti Amalia' ${ }^{2}$, Dedy Alfianto \\ ${ }^{1}$ Program Studi Teknologi Listrik, Fakultas Vokasi, Institut Teknologi Padang \\ ${ }^{2}$ Program Studi Teknik Elektro, Fakultas Teknik, Institut Teknologi Padang \\ Correspondence email: asnal.effendi@gmail.com ${ }^{1}$
}

\begin{abstract}
Abstrak - Energi terbarukan adalah energi yang dihasilkan dari sumber alami, seperti cahaya matahari, angin, hujan, arus pasang surut, dan panas bumi, yang terbarui atau secara alami dapat muncul kembali setelah dipergunakan. Dalam penelitian ini kajian keefektifan dan tingkat efisiensi penempatan pembangkit pada lokasi tertentu. Untuk itu perlu dirancang suatu alat bantu berbentuk data logger yang dipakai dalam pengambilan data parameter seperti intensitas cahaya, tegangan listrik, arus listrik, daya, suhu, kelembaban, kecepatan angin, dan lain lain. Dari penempatan data logger akan membantu uji dasar kelayakan pemakaian sumber energi nantinya. Data logger merupakan suatu sistem yang dapat melakukan perekaman otomatis parameter arus, tegangan, daya pada panel surya serta merekam secara otomatis kondisi suhu, kelembapan di bawah panel surya. Dari data logger terhadap pengukuran intensitas cahaya didapatkan rata-rata intensitas cahaya 798,24 Cd.
\end{abstract}

Kata Kunci : Intensitas Cahaya, DHT22, Data Logger, Panel Surya

Abstract - Renewable energy is energy produced from natural sources, such as light, wind, rain, tidal currents, and geothermal, which is renewable or can naturally reappear after being used. In this study, a study of the effectiveness and efficiency of power plants in certain locations. For this reason, it is necessary to design a tool in the form of a data logger that is used to collect parameter data such as light intensity, electric voltage, electric current, power, temperature, humidity, wind speed, and others. The placement of the data logger will help in the basic test of the feasibility of using energy sources later. Data logger is a system that can record automatic parameters of current, voltage, power on solar panels and automatically record conditions of temperature, humidity in the solar panel. The results of logger data on light intensity for a more efficient placement of solar panels occur at location 1 Beach behind Kmpus UBH 1, where at that location has an average light intensity of 798.24 Cd.

Keywords : Light intensity, DHT22, Data Logger, Solar panels

\section{PENDAHULUAN}

Penggunaan energi melalui panel surya merupakan alternatif yang paling potensial untuk diterapkan, namun faktor utama yang perlu dikaji yaitu dari segi penempatan panel surya [2].

Sebagai kajian dasar lokasi penempatan pembangkit Energi Baru Terbarukan akan berkaitan erat dengan parameter penting yang mempengaruhi nilai efisiensi pembangkitan energi baru terbarukan. Untuk mengukur parameter tersebut memerlukan suatu instrumentasi dan perekaman sebagai acuan analisa yang mampu menyatakan bahwa lokasi tersebut pantas menjadi lokasi pembangkitan Energi Baru Terbarukan, dengan objek pembangkit energi surya sebagai salah satu sumber energi baru terbarukan [3].

Untuk penempatan pembangkit pada lokasi tertentu, diperlu alat bantu berbentuk data logger yang dipakai dalam pengambilan data parameter seperti intensitas cahaya, suhu, dan data panel surya seperti tegangan listrik, arus listrik, kelembaban dan lain lain yang dapat melakukan perekaman data. Perekaman data tersimpan di SD card dan juga terunggah ke sistem cloud sehingga data dapat dimonitor secara real time.

\section{TINJAUAN PUSTAKA}

Proses monitoring PLTS menggunakan microkontroler arduino, pemilihan arduino disini kemampuan yang sudah cukup memadai untuk mendukung proses monitoring. Mikrontroler arduino juga dipakai oleh M. Mahendra [6] sebagai pendeteksi gangguan koneksi yang terjadi pada PLTS. Hasil ini terdapat tiga parameter yang dijadikan untuk menidentifikasi gangguang yaitu teganan pada panel (Vp), temperature panel (Tp) dan Resistansi panel (Rp) [5].

Manfaat menggunakan data logger melihat kemampuannya mengumpulkan data secara otomatis dalam beberapa periode. Data tersebut dapat diplot ke dalam grafik V-I dan grafik P-V untuk dianalisis. Dari hasil penelitian dan pengetesan tercatat daya maksimalnya mencapai 35W. Data logger dengan metode MPPT ini dapat digunakan sebagai perekam portabel untuk membandingkan daya di berbagai area [4].

Potensi sinar matahari menghasilkan energi listrik. Metode penelitian ini melakukan pengukuran secara langsung terhadap potensi energi listrik yang dapat dihasilkan oleh panel kapasitas $100 \mathrm{Wp}$ dengan jenis mono kristral. Peralatan digunakan adalah batere kapasitas 50 Ah, Inverter kapasitas 1000 Watt, Battery charge controller 12/24 Volt dan 10 A. Penelitian dilakukan tanggal $9-15$ maret 2019. Hasil dari pengujian pada tanggal 15 maret 2019, daya maksimal mencapai 99,9 Watt, terjadi pada jam 13,30 dengan 
intensitas cahaya matahari 95,500 Lux. Namun pada tanggal 11 maret 2019 jam 17.00 nilai intensitas cahaya matahari hanya 850 Lux sehingga daya keluaran 0,1 Wat [5].

\section{METODOLOGI}

\subsection{Metode Pengambilan Data}

Metode pengambilan data dapat dilakukan dengan data primer dengan melakukan observasi dan survey serta data skunder.

\subsection{Data-Data Yang Dibutuhkan}

Data yang dibutuhkan dalam penelitian ini adalah data hasil pengukuran intensitas cahaya dan suhu pada alat data logger, serta data BMKG Stasiun Meteorologi Maritim Teluk Bayur

\subsection{Flow Chart}

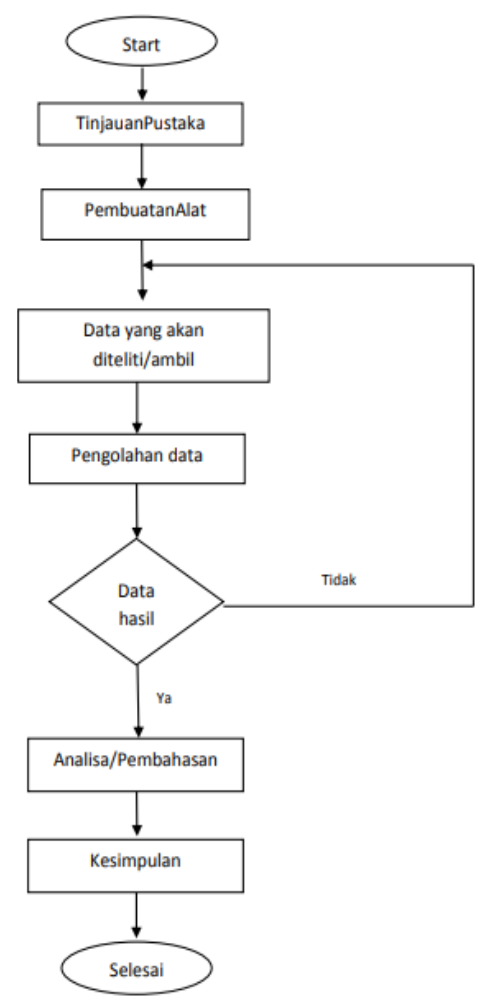

\section{HASIL DAN PEMBAHASAN}

Dalam melakukan penelitian digunakan peralatan dengan deskripsi alat yang dapat dilihat pada gambar 4.1.

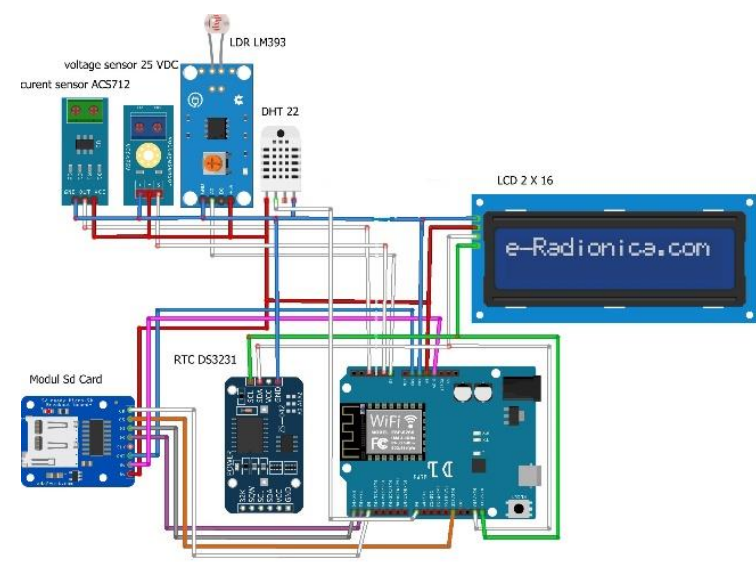

Gambar 4.1 Skema Rangkaian Data logger

Pada Gambar 4.1 menerangkan tentang skema rangkaian Data Logger, dalam hal ini dipakai dalam pengambilan data parameter seperti intesitas cahaya, suhu, kelembapan. Sistem yang dapat melakukan perekaman data otomatis yang tersimpan di SD card dan ke sistem WEB melalui internet, sehingga data dapat dimonitor secara real time.

Alat sistem menggunakan wifi controller dengan tipe ESP8266 NODEMCU mode Mega2560 dan Wemos D1 sebagai media kontrol penyimpanan database online dan offline, yang berfungsi sebagai wadah penyimpanan data logger untuk menyimpan data dari sensor berupa sensor intensitas cahaya yang akan membaca berapa banyak cahaya yang mengenai panel surya perwaktunya, kemudian sensor tegangan, sensor arus, sensor kelembaban dan suhu dengan tipe sensor DHT22.

Cara mengakses data yang ada pada alat, supaya bisa menampilkan data-data sensor secara online yang menggunakan IoT (Internet of Things) yaitu dengan menghubungkan wifi controller yang terdapat pada alat ke hospot atau modem portable ataupun jaringan internet yang tersedia pada lokasi saat alat diletakan.

Dimana ketika wifi kontroller telah terkoneksi dengan internet, maka dapat mengakses data secara online dengan mengetikan IP Address yang telah terprogram pada wifi kontroller, sehingga dapat melihat database sensor tersebut dari smartphone maupun web pada komputer atau laptop, sehingga pekerjaan monitoring sistem dapat dilakukan dengan mudah dan terstruktur.

\section{Tampilan Data Pada SD Card}

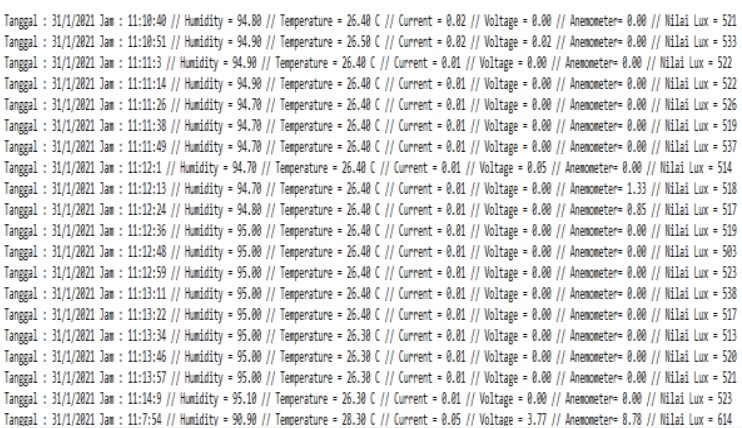


Gambar 4.2 Tampilan data pada SD Card

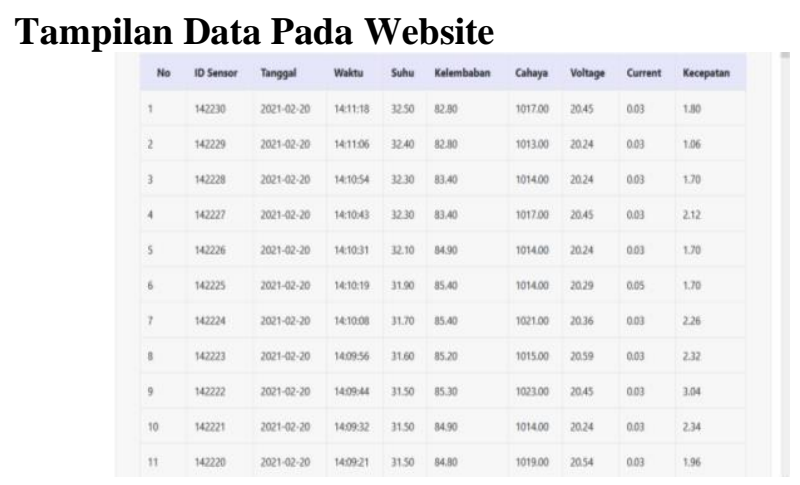

Gambar 4.3 Tampilan data pada website

\section{Grafik Hasil Pengujian Intensitas Cahaya Matahari}

a. Pengujian Intensitas Cahaya Matahari Rata-Rata Lokasi Pantai di belakang Kampus UBH 1

Tabel 4.1 Intensitas Cahaya Matahari Rata-Rata Lokasi Pantai di belakang Kampus UBH 1.

\begin{tabular}{|c|c|c|}
\hline No. & Jadwal Pengukuran & $\begin{array}{c}\text { Intensitas } \\
\text { Cahaya }(\mathrm{Cd})\end{array}$ \\
\hline 1 & Kamis. 21-01-2021 & 738.19 \\
\hline 2 & Jum'at. 22-01-2021 & 750.06 \\
\hline 3 & Sabtu. 23-01-2021 & 872.41 \\
\hline 4 & Minggu. 24-01-2021 & 735.89 \\
\hline 5 & Senin. 25-01-2021 & 709.51 \\
\hline 6 & Selasa. 26-01-2021 & 1017.65 \\
\hline 7 & Rabu. 27-01-2021 & 895.39 \\
\hline 8 & Kamis. 28-01-2021 & 754.85 \\
\hline 9 & Jum'at. 29-01-2021 & 743.56 \\
\hline 10 & Sabtu. 30-01-2021 & 765.89 \\
\hline
\end{tabular}

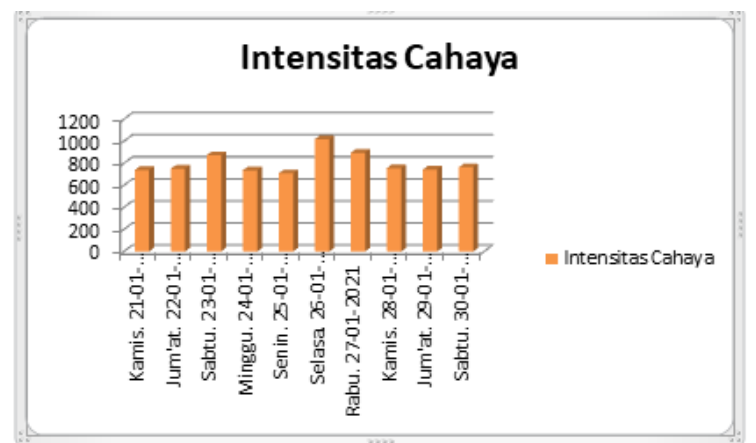

Gambar 4.4 Intensitas Cahaya Matahari Rata-Rata Lokasi 1 Pantai di belakang Kampus UBH 1.

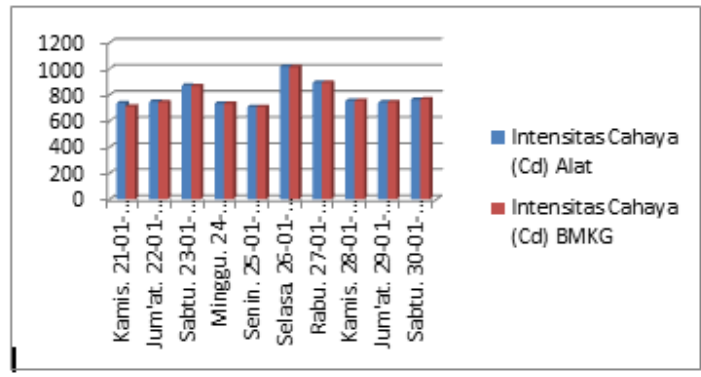

Gambar 4.5 Hasil Perbandingan Intensitas Cahaya Rata-Rata Dari Alat Dengan BMKG lokasi (Pantai di belakang Kmpus UBH 1).

Pada Gambar 4.5. Merupakan merupakan gambar perbandingan lokasi Pantai di belakang Kampus UBH 1, dimana gambar 4.5 diatas terdapat perbandingan antara data alat logger dengan data BMKG. Jadwal pengukuran pada lokasi ini dilakukan mulai dari tanggal 21 Januari 2021 sampai 30 Januari 2021.

Pada hari kamis tanggal 21 Januari 2021 terdapat intensitas cahaya dari alat sebesar $738.19 \mathrm{Cd}$ sedangkan intensitas cahaya dari BMKG sebesar $712.81 \mathrm{Cd}$ maka selisih perbandingannya sebesar $25.38 \mathrm{Cd}$.

Pada hari jum'at tanggal 22 Januari 2021 terdapat intensitas cahaya rata-rata dari alat sebesar $750.06 \mathrm{Cd}$ sedangkan rata-rata intensitas cahaya dari BMKG sebesar 745.64 Cd maka selisih perbandingannya sebesar $4.42 \mathrm{Cd}$.

Pada hari sabtu tanggal 23 Januari 2021 terdapat intensitas cahaya rata-rata dari alat sebesar $872.41 \mathrm{Cd}$ sedangkan rata-rata intensitas cahaya dari BMKG sebesae $870.32 \mathrm{Cd}$ maka selisih perbandingannya sebesar $2.09 \mathrm{Cd}$.

Pada hari minggu tanggal 24 Januari 2021 terdapat intensitas cahaya rata-rata dari alat sebesar $735.89 \mathrm{Cd}$ sedangkan rata-rata intensitas cahaya dari BMKG sebesar 733.54 maka selisih perbandingannya sebesar $2.35 \mathrm{Cd}$.

Pada hari senin tanggal 25 Januari 2021 terdapat intensitas cahaya rata-rata dari alat sebesar $709.51 \mathrm{Cd}$ sedangkan rata-rata intensitas cahaya dari BMKG sebesar 708.46 Cd maka selisih perbandingannya sebesar $1.05 \mathrm{Cd}$.

Pada hari selasa tanggal 26 Januari 2021 terdapat intensitas cahaya rata-rata dari alat sebesar $1017.65 \mathrm{Cd}$ sedangkan rata-rata intensitas cahaya dari BMKG sebesar $1015.53 \mathrm{Cd}$ maka selisih perbandingannya sebesar 2.12 Cd.

Pada hari rabu tanggal 27 Januari 2021 terdapat intensitas cahaya rata-rata dari alat sebesar $895.39 \mathrm{Cd}$ sedangkan rata-rata intensitas cahaya dari BMKG sebesar $894.57 \mathrm{Cd}$ maka selisih perbandingannya sebesar $0.82 \mathrm{Cd}$.

Pada hari kamis tanggal 28 Januari 2021 terdapat intensitas cahaya rata-rata dari alat sebesar $754.85 \mathrm{Cd}$ sedangkan rata-rata intensitas cahaya dari BMKG sebesar 755.32 Cd maka selisih perbandingannya sebesar $0.47 \mathrm{Cd}$. 
Pada hari jum'at tanggal 29 Januari 2021 terdapat intensitas cahaya rata-rata dari alat sebesar $743.56 \mathrm{Cd}$ sedangkan rata-rata intensitas cahaya dari BMKG sebesar 743.56 maka selisih perbandingannya sebesar 0 Cd.

Pada hari sabtu tanggal 30 Januari 2021 terdapat intensitas cahaya rata-rata dari alat sebesar $764.89 \mathrm{Cd}$ sedangkan rata-rata intensitas cahaya dari BMKG sebesar $766.36 \mathrm{Cd}$ maka selisih perbandingannya sebesar $1.47 \mathrm{Cd}$.

\section{KESIMPULAN}

Berdasarkan hasil penelitian dan pembahasan yang telah dilakukan oleh peneliti, maka dapat diambil kesimpulan sebagai berikut:

Hasil data logger terhadap intensitas cahaya untuk penempatan panel surya yang efisien lokasi Pantai di belakang Kampus UBH 1, dimana pada lokasi tersebut memiliki rata-rata intensitas cahaya 798,24 Cd, sedangkan selisih tertinggi terjadi pada hari kamis tanggal 21 Januari 2021 yaitu sebesar $25.38 \mathrm{Cd}$ sedangkan selisih intensitas cahaya terendah terjadi pada hari jum'at tanggal 29 Januari 2021 sebesar 0 Cd.

\section{DAFTAR PUSTAKA}

[1] M. Rif, S. Hp, M. Shidiq, R. Yuwono, and H. Suyono, "Optimasi Pemanfaatan Energi Listrik Tenaga Matahari di Jurusan Teknik Elektro Universitas," vol. 6, no. 1, pp. 44-48, 2012

[2] M. Abrori, "Pemanfaatan Solar Cell Sebagai Sumber Energi Alternatif dan Media Pembelajaran Praktikum Siswa Di Pondok Pesantren ' Nurul Iman' Sorogenen Timbulharjo, Sewon, Bantul, Yogyakarta Menuju Pondok Mandiri Energi," vol. 1, pp. 17-26, 2017

[3]H. Suryawinata, D. Purwanti, and S. Sunardiyo, "Sistem Monitoring pada Panel Surya Menggunakan Data logger Berbasis ATmega 328 dan Real Time Clock DS1307," vol. 9, no. 1, 2017

[4] A. Effendi, A.Y. Dewi, F. Ismail, 2018. Data Logger Development to Evaluate Potential Area of Solar Energy. MATEC Web of Conferences 215, 01014 (2018) ICTIS 2018.

[5] Mahbubur. M. rahman, J. Selvaraj, N.A. Rahim, M. Hasanuzzaman, "Glba modern monitoring system for PV based power generation"” ,Renewable and Suitainable Energy review, Elsevier., 2017.

[6] M. Mahendran, V. Ananddharaj, K. Vijayavel, and D. Prince Winston, "Permanen Mismatch faultch identification of photovoltaic cell using arduino," ICTACT Journal on Microelectronic, 2015.

[7] H. Asyari1, R. A. Firmansyah, M. Kusban, "Analisa Tingkat Potensi Sinar Matahari Untuk Pembangkit Listrik Tenaga Surya Di Daerah Pantai," Simposium Nasional RAPI XIX FT UMS ISSN 1412-9612, 2020.
[8] Wilson W.W., 1996: Teknologi Sel Surya : Perkembangan Dewasa Ini dan yang Akan Datang, Edisi ke empat, Elektro Indonesia, Jakarta.

\section{Biodata Penulis}

Asnal Effendi, Menyelesaikan S1 Teknik Elektro di Sekolah Tinggi Teknik Padang (sekarang Institut Teknologi Padang) pada tahun 1999, menyelesaikan S2 Teknik Elektro di Universitas Gadjah Mada pada tahun 2007, saat ini mengajar di Institut Teknologi Padang pada Program Studi Teknologi Listrik dengan bidang riset Energi Terbarukan dan Power System.

Arfita Yuana Dewi, Menyelesaikan S1 Teknik Elektro di Sekolah Tinggi Teknik Padang (sekarang Institut Teknologi Padang) pada tahun 1999, menyelesaikan S2 Teknik Elektro di Universitas Gadjah Mada pada tahun 2007, saat ini mengajar di Institut Teknologi Padang pada Program Studi Teknologi Listrik dengan bidang riset Sistem Tenaga Listrik dan Power System.

Siti Amalia, Menyelesaikan S1 Teknik Elektro di Universitas Andalas pada tahun 2011, menyelesaikan S2 Teknik Elektro di Intitut Teknologi Bandung 2015, saat ini mengajar di Institut Teknologi Padang pada Program Studi Teknologi Listrik dengan bidang riset Sistem Tenaga Listrik dan Power System.

Dedy Alfianto, Menyelesaikan pendidikan Sarjana Teknik Elektro di Institut Teknologi Padang Jurusan Teknik Elektro pada tahun 2021. 